\title{
Evaluation and frequency of KELL erythrocyte antigen in blood donors of Regional Blood Center of Passo Fundo, Brazil
}

\author{
Avaliação e frequência do antígeno KELL eritrocitário em doadores de \\ sangue do Hemocentro Regional de Passo Fundo, Brasil
}

Recebido em: 19/01/2018 Aceito em: $\quad 05 / 12 / 2018$
Danury Dal Piva BALDASSO ${ }^{1}$; Jéssica Zolim Andreatto MANDELLI'; Anelise EHRHARDT $^{2}$; Renata Eliane BOEHM ${ }^{3}$; Alexandre EHRHARDT ${ }^{1}$.

${ }^{1}$ Universidade Luterana do Brasil - ULBRA, Campus Carazinho. BR 285, KM 335.

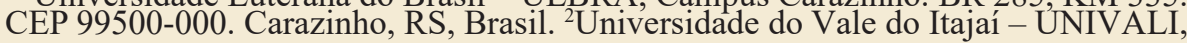
Campus Itajaí. Rua Uruguai, 458, CEP 88302-901. Itajaí, SC, Brasil. ${ }^{3}$ Serviço de Hemoterapia - Hospital de Clínicas Universidade Federal do Rio Grande do Sul - UFRGS, Rua Ramiro Barcelos 2350, CEP 90035-903. Porto Alegre, RS, Brasil. E-mail: bioquimicoalexandre@gmail.com

\section{ABSTRACT}

The aim of this research was verify the frequency of erythrocyte antigen K1 in the population of donors who had their blood phenotyped at Regional Blood Center of Passo Fundo (RS). This descriptive study of documental approach was conduct through retrospective evaluation of record spreadsheets for all donors phenotyped during the period of July 2010 to June 2015. An absolute verification was done, comparing the number of donors without the expressed antigen KELL and the number of donors who had this antigen on the erythrocyte membrane. From 1,163 phenotyped donors, 80 (7\%) showed antigen expression in the erythrocyte membrane, being lower number than reported in the literature. Despite the percentage found for the K1 expression be lower than is described by other authors, the antigen must be identified because its immunogenicity has great clinical relevance and may result in transfusion complications.

Keywords: blood group antigens; system Kell blood group; transfusion reaction; blood transfusion.

\section{RESUMO:}

O objetivo desta pesquisa foi verificar a frequência do antígeno eritrocitário K1 na população de doadores que tiveram seu sangue fenotipado no Hemocentro Regional de Passo Fundo (RS). Este estudo descritivo de abordagem documental foi realizado por meio de avaliação retrospectiva de planilhas de registro de todos doadores fenotipados durante o período de julho de 2010 a junho de 2015 . Na análise, foi realizada uma verificação absoluta comparando o número de doadores sem o antígeno expressado KELL e o número de doadores que apresentavam esse antígeno na membrana eritrocitária. Dos 1.163 doadores fenotipados, $80(7 \%)$ apresentaram expressão antigênica na membrana eritrocitária, sendo menor que o relatado na literatura. Apesar da porcentagem encontrada para a expressão de K1 ser menor do que a descrita por outros autores, o antígeno deve ser identificado porque sua imunogenicidade tem grande relevância clínica e pode resultar em complicações transfusionais.

Palavras-chave: antígenos de grupos sanguíneos; sistema do grupo sanguíneo de Kell; reação transfusional; transfusão de sangue. 


\section{INTRODUCTION}

The discovery of the first erythrocyte antigens ( $\mathrm{ABO}$ and $\mathrm{Rh}$ ) in the twentieth century was a significant advance in transfusion safety because until the time of designation of these antigens transfusion therapy had been shown clinically dangerous due to the varying blood incompatibility between donor and recipient. The finding of researchers as Landsteiner increased the reliability of blood transfusion contributing much to do researches to generate the establishment of new erythrocyte antigens (1).

The antiglobulin test described in 1945 by Coombs, Mourant, Race allowed the recognition of various blood antigens (2). One of these antigens discovered was K1 (KELL), described more specifically in the year 1946. It was the first to be reported by the new method of great clinical relevance for the high ability to induce an immune response, being the most important antigen of the KELL group. After that, were identified other antigens of the group, totalling 35 known until today, these make up the KELL system that is considered the third most polymorphic group, with high power of immunogenicity and could result in severe transfusion reactions. These antigens are expressed on the surface of the erythrocyte membrane, but can also be found in the brain, lymphoid organs, skeletal muscle, pancreas, testes, heart and myeloid progenitor cells (3). According to Girello and Kühn (2002), Kell group comprises an N-glycosylated glycoprotein type II $93 \mathrm{kD}$, having as its main physiological function proteolytic action with bioactive peptides activation and interaction with another protein known as XK which apparently is associated with membrane transport processes, but still does not know its specific action (4).

The antibodies of Kell system, such as anti-K, are clinically significant for being the IgG class these antibodies can lead to the development of hemolytic disease of the fetus and newborn (HDFN) and transfusion reactions. When present in the fetus, and later in the newborn, can lead to severe anaemia due to the inhibitory effect of erythropoiesis, but their concentration is not associated with the severity of HDFN as in anti-D antibodies (4).
The Transfusion Medicine (TM) is a science that has been showing continued growth with progress and decisive changes, generating future development promises not only in Brazil but in several countries. Transfusional therapeutics is one of the interventions of crucial importance within medicine, and for not being without risks, it is an extremely complex procedure (5). This therapy includes the correct use of blood components and hemoderivative, as well as the selection of these, featuring TM as a specialty with multiple functions, including the assessment of patients who develop transfusion reactions and those with autoantibodies and alloantibodies, as well as integrating all stages accomplished in a blood bank until the infusion into the patient (6).

The infusion procedure has as purpose to grant patient the erythrocytes in the proper state to overlive after transfusion and exercise their function, ensuring safety for the recipient in question. For this, the donor's erythrocytes compatible with the receiver must go through a selection that encompasses immuno-haematological tests to provide blood infusion (7).

Transfusion shall be evaluated with caution because the comparison of the expected benefits against the potential dangers guarantees the transfusion safety. The case where assessment is done improperly, the transfusion procedures can lead to the development of diseases transmitted via hematogenic means, awareness and immunisation, and may cause severe consequences to the transfused patient (6). These consequences caused by the transfusional practice of blood products and hemoderivative are commonly called the transfusional reactions. Among them stands out: acute hemolytic anaemia, alloimmunization and even death as a consequence of anaemia (8).

Acute hemolytic anaemia is often caused by incompatible transfusion of $\mathrm{ABO}$ red blood cell concentrate, naturally occurring antibodies; in this case, they react with antigens $\mathrm{A}, \mathrm{B}$ or $\mathrm{AB}$ of the donor, causing intravascular hemolysis. This reaction is feared for its severity and high mortality rate (9). The genetic disparities between donor and recipient cause alloimmunization. In this case, there is the formation of non-specific antibodies due to the infusion of unknown antigens to the immune system 
of the patient. The risk of developing alloantibodies depends on exposure and immunogenicity of the receptor and is defined as the ability of antibody production against foreign antigens. In patients receiving multiple transfusions, the percentage of developing clinically important alloantibodies is $30 \%$, which can lead to problems, especially when there is a need for constant transfusion therapy (10).

Considering the relevance of the $\mathrm{K} 1$ antigen identification for hemotherapy services, this study has as purpose to scale the frequency of erythrocyte antigen in the population of phenotyped donors of the Regional Blood Center of Passo Fundo, RS, Brazil.

\section{METHODS}

Descriptive study with a quantitative approach, of documental character held at the Regional Blood Center of Passo Fundo through retrospective evaluation of the record spreadsheets of all donors who underwent phenotyping in the period July 2010 to June 2015 meeting ethics established in the guidelines and requirements of Resolution No. 466/12 of the National Health Council (CNS / MS) (11).

For the study, were selected all donors who met the following inclusion criteria: donors of both genders submitted to antigen test $\mathrm{K} 1$ with medical records in this period of five years; and those presenting the expressed antigen. The exclusion criteria: patient not registered, or have not undergone the antigen research, recorded out of time or those without the K1 antigen. The determination of the Kell antigen was carried out by DiaClon RhSubgroups $+K$ (BioRad). Since the selection of donors obeying the inclusion criteria were evaluated socio-epidemiological data from the $\mathrm{K} 1$ express donors such as gender, age, race and blood type.

Analysis of these data was based on frequency tables without using the sample size calculation was performed only an absolute verification by comparing the number of donors without K1 expressed antigen and the number of donors who possess this antigen on the erythrocyte membrane, checking especially if this number is significantly important in transfusional practice.
This study was approved by the Research Ethics Committee in Human Beings of the Lutheran University of Brazil - ULBRA, according to the rules of Resolution No. 466/12 that guides the research with human beings, under protocol number 45963215.2.0000.5349 and authorised by General Direction of Regional Blood Center of Passo Fundo (RS).

\section{RESULTS AND DISCUSSION}

Between July 2010 June 2015 at the Regional Blood Center of Passo Fundo, were subjected to blood phenotyping 1,163 donors, of the 57,053 blood donations, which represents $2 \%$ of the total number of donations. Among the 1,163 donors phenotyped 80 had the $\mathrm{K} 1$ antigen expressed on the erythrocyte membrane, representing $7 \%$ of total donors submitted to phenotyping. The frequencies of gender-related antigen were observed that men had $55 \%$ of the antigen expression while the women presented $45 \%$.

Considering that the $\mathrm{K} 1$ antigen displays specificity related to races (Caucasoid or Black), the Caucasian population showed a higher number of $\mathrm{K} 1$, among the 80 donors, $78(97.5 \%)$ of them were Caucasians, and other $2(2.5 \%)$ were Black. Analysing by the number of phenotyped the percentage of $\mathrm{K} 1$, donors expressing in the Caucasian population were $6.7 \%$, and $0.3 \%$ Black.

The survey also evaluates the presence of the antigen about the blood group donors. Blood group "'O" was the one with the highest percentage, with the further results presented in Figure 1.

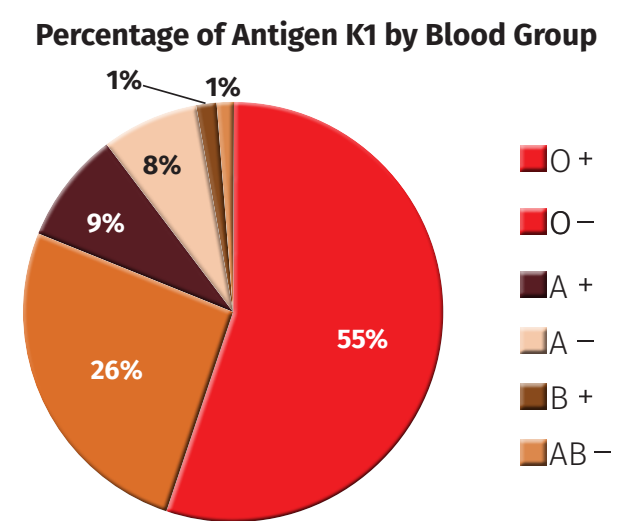

Figure 1. K1 frequency by blood group ( $n=80)$ among blood donors at Regional Blood Center of Passo Fundo, Brazil 
Also, the data regarding the age of these donors were analysed. The table below shows all the results divided into age groups.

Table 1. K1 expression among blood donors at Regional Blood Center of Passo Fundo, Brazil

\begin{tabular}{|ccc|}
\hline Age range & $\mathbf{n}$ & $\mathbf{\%}$ \\
\hline $18-30$ & 8 & 10 \\
\hline $31-40$ & 28 & 35 \\
$41-50$ & 22 & 27.5 \\
\hline
\end{tabular}

The antigens of KELL system are classified according to their frequency. According to Harmening (2006), the rate varies among populations of the world because it is dependent on the ethnicity of each region. Harmening also reported that the $\mathrm{K} 1$ antigen is considered low frequency to be present in a small part of the population. These data are agreeing with the results found in this study regarding the frequency of the K1 antigen in the search area, other antigens of KELL system, are considered high frequency because they are present in over $90 \%$ of the population, as the antigen $\mathrm{k}$ (Cellano) (12).

These data shall be considered only for the Rio Grande do Sul State, where more than 67\% of the population belong to the Caucasian group, mainly due to being colonised by Europeans (13). The frequency found in this study has a lower percentage for antigen expression both for the Caucasian as the Black, pointing resemblance to some authors as Beiguelman (2003), which described that $9 \%$ of the Caucasian population has the $\mathrm{K} 1$ antigen, and the percentage of Black is even smaller, 1 to $3 \%$ (14). Considering that the study area has a predominance of European descent, the results also confirm what Flôres et al. (2013) reported, that the frequency of antigen is from 4 to $9 \%$ in the European population and is absent in Asian populations (15).

As may be observed in Figure 1, a higher proportion of K1 was found among the donors of blood group "O" positive (55\%) considering that of 57,053 donations, 23,677 (42\%) had blood group "O" positive in frequent antigen expression may be related to the number of donations from individuals in that group. But the "O" negative represents the second group most frequently expressing K1, with $26 \%$ of all expression, if we compare the total number of donations made by donors "O" negative $(4,582,8 \%)$. The number of $\mathrm{K} 1$ in this blood group is relatively high, not correlate with the number of donations made by individuals in this group. However, we do not find references in the literature to report the presence of specific antigen by group, or even a higher frequency blood group. The groups "B" negative and "AB" positive are not showed in the graph due to there was not any individual presenting antigen expression among the subjects. In relation to the Rh, Bortolotto et al. (2011) evaluated the frequency of the $\mathrm{Rh}$ and KELL phenotype in Santa Maria, a nearby this research area and described a high percentage of $\mathrm{K} 1$ in $\mathrm{Rh}$ negative donors; this was also being perceived by the results highlighted in this work, especially in relation to " $\mathrm{O}$ " negative.

The result founded of $81 \%$ of presence of $\mathrm{K} 1$ expressed in the group "O" may be related to the number of donations by " $O$ " positive group or also by the fact that the group "O" negative be characterized as universal donor and preconized by Blood Centers that the majority of test to be performed be made with this type of blood, in order to find a phenotype, which may be transfused to recipients with blood type $\mathrm{A}, \mathrm{B}, \mathrm{AB}$ or $\mathrm{O}$ and $\mathrm{Rh}$ negative or positive.

Although it is not found data to have relating antigen expression with age, a higher number of $\mathrm{K} 1$ was expressed among donors between 31 and 40 years. According to the National Health Surveillance Agency (17), data collected in 2006 showed $27 \%$ of blood donor profile in southern Brazil had between 30 and 39 years, being the highest percentage of outstanding age group. Therefore, the results presented in this study may be related to the number of donations from individuals in this age group having no relation to the antigen in question.

It was observed that the presence of K1 was higher in the male population, but this percentage was not relevant. As far we know, 
there is no data in the literature reporting that the male has a specific relationship with the expression of the antigen and even if there is a higher frequency in a given gender, the result in men may be due to the high number of donations made by them. As described by Zago et al. (2010) in their study in Pelotas (RS), the male population showed high participation in blood donations (18), as well as Araújo et al. (2010), in a study in the Public Blood Center of Recife where male donors accounted for $77 \%$ of the total (19).

Another fact that deserves mention is the total of donations that were performed by these donors in the studied period (5 years). One hundred ninety-two positive $\mathrm{K} 1$ bags were transfused during this period on probable recipients with a compatible phenotype for the antigen. This may be associated with the used of the rare blood donors' database, after being submitted to phenotyping and determined to be $\mathrm{K} 1$, expressed phenotype are included in this database and thus can be assessed when a receiver, usually chronic, having the same phenotype, requires transfusion. Even though phenotyping is highly relevant to meet the transfusion needs and map out an erythrocyte antigenic profile of its donors, it was noted that only $1,163(2 \%)$ of phenotyping were performed at the Regional Blood Center of Passo Fundo. This result is relatively low when compared to the total of donations received $(57,053)$. The blood phenotyping aims to ensure a safer transfusion therapy, so this test allows the identification of the antigen present in the erythrocyte membrane of donors and recipients, using specific antisera against certain antigens by choosing units of erythrocytes, determining a transfusion process phenotype compatible and minimising the risks of transfusion (20). However, in most blood transfusion services, phenotyping erythrocyte for more immunogenic antigens is usually held only for transfusions in patients with chronic blood disorders (21), therefore, most donated erythrocyte units are not tested for antigen KELL (K1) as shown in this study, resulting in the possibility of alloimmunization, especially in receptors which present multiple blood transfusions.
The increase in the need for blood transfusions contributed with the increasing production of non$\mathrm{ABO}$ alloantibodies erythrocytic, that in general is due to technological advancement and improvement of life expectancy has made the surgeries more complex, thus requiring such a procedure. Most haemotherapic services perform the pre-transfusion compatibility and phenotyping tests only for patients with special needs, such as receivers with sickle cell anaemia and thalassemia. Researches related to alloimmunization are commonly conducted just before a new transfusional event that is, from the second transfusion requested to the patient, and thus cannot detect alloantibodies produced in the first transfusion or because there are no new indications of the procedure or even due to the title of these antibodies declined over time (21). When these antibodies are no longer detectable, and the evidence for irregular antibodies becomes insufficient, the patient becomes exposed to the risk of developing late transfusion hemolytic reactions (10). It happens when the receiver needs a new blood infusion and receives antigen for which he was already sensitised, and the immune memory will cause a faster secondary reaction that the first transfusion, resulting in transfusion complications (21).

The study conducted by Alves et al. (2012) showed a considerable frequency of alloimmunization in non-chronic receptors concentrates of erythrocytes, and the most produced alloantibodies are possessors of clinical significance and directed to the $\mathrm{Rh}$ and KELL system antigens (21). It also describes that irregular antibodies have been associated to the majority of fatal transfusion reactions and considered the second most significant cause of death related to blood transfusion reported to the FDA (Food and Drug Administration) in recent years.

For this reason Osaro et al. (2015) conducted a research to know the KELL distribution in pregnant women in Sokoto, point out that there is a need for routine screening for clinical significance antibodies in pregnant women, as well as recommend that in the first prenatal visit must be held research to the most immunogenic antigens (24). The study also suggested to stock up negative K1 erythrocytes units for use in all pregnant women and women of 
childbearing age who require transfusion. This is recommended by the Brazilian Ministry of Health (25) in its guide To Use Of Blood Components, as well as it is determined the use of negative units in patients with negative screening of irregular antibodies, but with possible entry into chronic transfusion scheme, however, in the routine of haemotherapic services are not commonly performed research for the immunogenic antigens in any of the two prominent groups.

Therefore, according to Rani et al. (2015) determining the frequency of red cell antigens in a population is useful for the knowledge of ethnic distribution, besides the formulation of databases for the supply of compatible negative blood to the receiver with multiple alloantibodies (26). Hemolytic transfusion reactions due to incompatibility related to KELL system is of significant importance, as in HDFN; it is suggested that the typing, as well as others similar related test to KELL system, should be implemented at least for all multi-transfused patients, giving a big step to improve transfusion safety.

\section{REFERENCES}

1. Alves VT. Frequência de Aloanticorpos Irregulares Antieritrocitários em Receptores de Concentrados de Hemácias Atendidos com Emergências Médicas e/ou com Doenças Agudas no Hospital de Clínicas da UFTM [Tese]. Uberaba: Universidade Federal do Triângulo Mineiro. 2010.

2. Zago MA; Falcão RP; Pasquini R. Hematologia Fundamentos e Prática. $1^{\circ}$ ed São Paulo, Brasil: Editora Atheneu; 2004.

3. Denomme G. Kell and $\mathrm{Kx}$ blood group systems. Immunohematol/Am Red Cross. 2016; 31: 14-19.

4. Girello AL, Kuhn TIBB. Fundamentos da imunohematologia eritrocitária. $1^{\mathrm{a}}$ Ed. São Paulo, Brasil: SENAC; 2002.

5. Iwamoto $\mathrm{HH}$; Silva KFN; Soares S. A prática transfusional e a formação dos profissionais de saúde. Rev Bras Hematol Hemoter. 2009; 31(6): 421-426. DOI: 10.1590/S1516-84842009005000092.

6. Boral LI; Henry JB; Weiss ED. Medicina Transfusional. In: Henry JB. Diagnósticos e tratamentos por métodos laboratoriais. $20^{\circ}$ Ed. Barueri: Manole, 2008.

\section{CONCLUSION}

The present study demonstrates the importance of determining and evaluating the frequency of the $\mathrm{K} 1$ antigen in blood donors. The number of K1 found in the population of the Regional Blood Center of Passo Fundo, despite being lower than that described in the literature, shall not be treated as irrelevant because the high power of immunogenicity of the antigen demonstrates how important is to identify it in the transfusional practice. This study highlights the need for expansion of erythrocyte phenotyping in all blood donors and suggests carry out further studies involving a more significant number of phenotyped donors so that it can be justified that the low percentage of $\mathrm{K} 1$ is characteristic of the survey region.

\section{ACKNOWLEDGEMENT}

The authors would like to thank Claudete Mistura Doro, Head of the Passo Fundo Regional Blood Center.

7. Kahar MA; D. Patel R. Phenotype frequencies of blood group systems (Rh, Kell, Kidd, Duffy, MNS, P, Lewis, and Lutheran) in blood donors of south Gujarat, India. Asian J Transfus Sci. 2014; 8(1):51-55. DOI: 10.4103/09736247.126693

8. Ferreira O; Martinez EZ; Mota CA; Silva AM. Avaliação do conhecimento sobre hemoterapia e segurança transfusional de profissionais de Enfermagem. Rev Bras Hematol Hemoter. 2007; 29(2):160-67. DOI: 10.1590/ S1516-84842007000200015

9. Oliveira LCO, Cozac APCNC. Reações transfusionais: Diagnóstico e tratamento. Rev USP. 2003;36(2/4):43138. DOI: $10.11606 /$ issn.2176-7262.v36i2/4p431-438

10. Lin Y; Saskin A; Wells RA; Lenis M; Mamedov A; Callum J; Buckstein R. Prophylactic RhCE and Kell antigen matching: impact on alloimmunization in transfusion-dependent patients with myelodysplastic syndromes. Vox Sanguinis. 2017; 112: 79-86

11. BRASIL. Conselho Nacional de Saúde e Ministério da Saúde. Resolução n ${ }^{\circ} 66 / 12$ de 12 de Dezembro de 2012. Orienta a pesquisa com seres humanos. Brasilia, DF; 2012. 
12. Harmening DM. Técnicas Modernas em Bancos de Sangue e Transfusão. $4^{\circ}$ ed. Rio de Janeiro, Brasil: Revinter; 2006.

13. IBGE - Instituto Brasileiro de Geografia e Estatística. Censo demográfico; 2010.

14. Beiguelman B. Os Sistemas Sanguíneos Eritrocitários. $3^{\mathrm{a}}$. ed. Ribeirão Preto, Brasil: FUNPEC; 2003.

15. Flôres MALR, Visentainer JEL, Guelsin GAS, Fracasso AS, De Melo FC, Hashimoto MN, Sell AM. Rh, Kell, Duffy, Kidd and Diego blood group system polymorphism in Brazilian Japanese descendants. Transfus Apher Sci. 2013;50 (1):123-28. DOI: 10.1016/j.transci.2013.09.014

16. Bortolotto AN, Mikalauscas MM, Murari Al, Rubin S,Silva JEP. Frequência do sistema Rh e Kell nos doadores do hemocentro de Santa Maria - RS. Rev Saúde 2011; 37(2):49-56. DOI: 10.5902/223658343025

17. BRASIL. Agência Nacional de Vigilância Sanitária. Tabela Doadores Região Sul. ANVISA - ; 2006.

18. Zago A, Da Silveira MF; Dumith SC. Prevalência de doação de sangue e fatores associados. Rev. Saúde Pública. 2010; 44(1):112-20. DOI: 10.1590/S003489102010000100012.

19. Araujo FMR, Feliciano KVO, Mendes MFM, Figueiroa JN. Doadores de sangue de primeira vez e comportamento de retorno no hemocentro público do Recife. Rev Bras Hematol Hemoter. 2010; 32(5): 384-90. DOI: 10.1590/ S1516-84842010000500011.

20. Carmo KPDS. Técnicas utilizadas para seleção de unidades de concentrado de hemácias em pacientes com anemia hemolítica auto-imune. [Trabalho de Conclusão de Curso]. Marília: Faculdade de Medicina de Marília. 2013.

21. Alves VM, Martins PRJ, Soares S, Araújo G, Schmidt LC, Costa SSM, Langhi DM, Moraes-Souza H. Pesquisa de aloimunização após transfusão de concentrados de hemácias em um estudo prospectivo. Rev Bras Hematol Hemoter. 2012; 34 (3): 206-11. DOI: 10.5581/15168484.20120051

22. Costa FV. Estudo dos incidentes transfusionais imediatos ocorridos no hospital universitário da Universidade Federal de Santa Catarina. [Trabalho de Conclusão de Curso]. Florianópolis: Universidade Federal de Santa Catarina. 2006.

23. Zimring JC; Johnsen JM. Keeping the Kell away from immunity. Blood J. 2012; 119(23):5346-348. DOI: 10.1182/blood-2012-04-423947

24. Osaro E, Ladan MA, Zama I, Ahmed Y, Mairo H. Distribution of Kell phenotype among pregnant women in Sokoto, North Western Nigeria. Pan African Medical Journal.2015; 21 (301). DOI: 10.11604/ pamj.2015.21.301.4636

25. BRASIL.Ministério da Saúde. Guia para uso de hemocomponentes. Brasília: Ministério da Saúde; 2010.

26. Rani R; Sharma N; Bedi D; Aditi AS; Sharma R. Incidence of Kell blood group in blood donors: A population-based study. Asian J Transfus Sci. 2015; 9(1):107-108. DOI: 10.4103/0973-6247.150978 